\title{
SCIDiC
}

International Journal of Dentistry and Oral Science (IJDOS)

ISSN: 2377-8075

\section{Prevalence of Partial Edentulism and its Association to Gender}

Research Article

Dhinesh Kumar Sanggaya ${ }^{1}$, Dr. Visalakshi Ramanathan ${ }^{2 *}$

${ }^{1}$ Saveetha Dental College and Hospitals, Saveetha Institute of Medical and Technical Sciences(SIMATS), Saveetha University, Chennai 600077, Tamil Nadu, India.

${ }^{2}$ Senior Lecturer, Department of Prosthodontics, Saveetha Dental College and Hospitals, Saveetha Institute of Medical and Technical Sciences(SIMATS), Saveetha University, Chennai 600077, Tamil Nadu, India.

\section{Abstract}

Edentulism (partial or complete) is an indicator of the oral health of a population. Partial edentulism is loss of one or more teeth in one arch due to various reasons like dental caries, periodontitis, trauma, cystic lesions. Partial edentulism not only causes lifestyle compromise but also affects patient's quality of life. Partial edentulism when not addressed leads to compromised occlusion, altered speech, changes in appearance, TMJ problems. The partial edentulism pattern has been observed globally in different populations. The aim of the present study was to assess the prevalence of partial edentulism based on kennedy's classification, evaluate if Gender has a positive or negative correlation with Partial edentulism. A retrospective evaluation was conducted in the Department of Prosthodontics, Saveetha Dental College by examining the patient record system of the faculty. The study is conducted to find out the prevalence of partial edentulism and its correlation to gender. The study sample consisted of 400 patients who were partially edentulous. Study population consisted of 400 patients of which 220 were males and 180 females. The most prevalent type of partial edentulism is Kennnedy's Class III among both genders.

Keywords: Gender; Kennedy's Classification; Partial Edentulism.

\section{Introduction}

Partial edentulism or complete tooth loss is prevalent worldwide among elderly. Earlier studies have shown that edentulism affects the health and the overall quality of life of the older generations. $[3,38]$ An edentulous span is a gap in the dental arch created due to loss of one or more tooth [22, 35] Several causes of edentulism are dental caries, periodontal diseases, trauma, orthodontic treatment, impacted tooth, hypoplasia, supernumerary teeth, neoplastic and cystic lesions $[12,37]$. The primary purpose of a classification of partially edentulous arches is to identify potential combinations of teeth to edentulous ridges in order to facilitate communication among dental colleagues, students, and technicians $[20,34,42]$.

There are numerous classifications which have been proposed to classify the partially edentulous arches on the basis of the potential combinations of teeth to 4 ridges $[16,45]$. Among which currently, Kennedy's classification is probably the most widely accepted one. Kennedy divided all partially edentulous arches into four main groups. In the classification, edentulous areas, other than those determining the main types, were designated as modification spaces [4, 5, 43]. The Kennedy's classification is as follows. Class I, Bilateral edentulous areas located posterior to the remaining natural teeth. Class II, A unilateral edentulous area located posterior to the remaining natural teeth [7, 23]. Class III, A unilateral edentulous area with natural teeth remaining both anterior and posterior to it. Class IV, A single, but bilateral (crossing the midline) edentulous area located anterior to the remaining natural teeth $[2,11]$. Studies on self-perception have shown that tooth loss is associated with aesthetical, functional, psychological, and social impacts on individuals.Partial edentulism is one of the widely studied topics in dentistry [15].

Several studies have analysed the correlation between partial edentulism and its influencing factors like age and gender. Few studies also have analysed the awareness among the subjects to replace the missing teeth. Surveying of RPD patients visiting clinics, clinical records and population in a particular locality have been the common method of evaluation of partial edentulism. Most commonly, recording patient partial edentulism is done by gathering details through clinical examination. Previously our team has

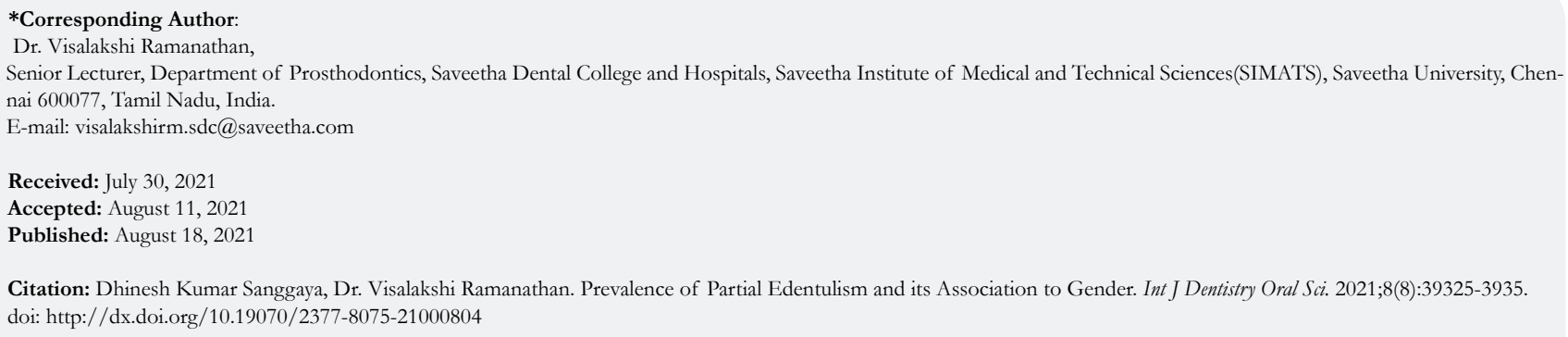

Copyright: Dr. Visalakshi Ramanathan 2021 . This is an open-access article distributed under the terms of the Creative Commons Attribution License, which permits unrestricted use, distribution and reproduction in any medium, provided the original author and source are credited. 
a rich experience in working on various research projects across multiple disciplines $[1,6,9,10,17,18,25,27,29,30,39,40,44$, $48,49]$. Now the growing trend in this area motivated us to pursue this project.

\section{Materials and Methods}

This Study was performed in a university setting. The data for the study was collected by reviewing patient records from the Faculty of Prosthodontics, Saveetha Dental College and the data was assessed from the time period of June 2019 to April 2020 in this retrospective evaluation. From the patient records all partially edentulous cases were included into the study. Ethical clearance was obtained from the Institutional Ethics Committee of Saveetha Dental College. The cross checking of data including digital entry and photographic data entry was done. The main advantages of this study was that the data was all prevalidated and the main disadvantage was that it was an unicentric study and only a single ethnicity of the population was studied. After retrospective data collection done by the researcher. The data on following variables were tabulated: Gender and Kennedy's classification. The data was randomly cross verified by faculty of prosthodontics. The sample size consisted of 400 patients. The internal validation was done by complete data collection and verification of data institutionally.

\section{Results \& Discussion}

There were 400 patients involved in the study out of which $55 \%$ of the study participants are males and $45 \%$ are females. (Figure 1). Kennedy's Class III is the most prevalent in both male and females; $32.5 \%$ in males and $31 \%$ in females. Kennedy's Class I is $5.25 \%$ among males which is the least among that particular gender and $4.25 \%$ in the female study population. Kennedy's Class
II is $8.5 \%$ among males and $6.75 \%$ among females. $8.35 \%$ of the population with Kennedy's class IV are males and $3 \%$ are females (Figure 2).There is a statistically significant difference between gender and partial edentulism among the study population.(Figure 3 , Table 1).

The main usage of Kennedy's classification in this study for partial edentulism is for the ease of description of partially edentulous cases. In this study, Kennedy classification is used because it simplifies the description of partial edentulism, allows immediate visualization of the partially edentulous arch, provides a logical way to display the problems of design, and to simplify the application of basic principles of partial denture design. In this study, it was observed that Kennedy's Class III is the most common among both males and females. 220 males and 120 females were included in this study as samples. Partial edentulism is more common in males than females. Kennedy's Class III, which is the most common seen in 130 males and 124 females.The present study was initiated to assess the prevalence and pattern of partial edentulism. According to previous study conducted by Ashraf et al., [19] the commonly occurring type of partial edentulousness was Kennedy's Class III in maxilla comprising 23.3 percent and in mandible 22.1 percent .The prevalence of tooth loss is more prevalent in males which is 58.2 percent while in females are 41.8 percent [19]. In another study by Manimaran et al., [19, 20. Kennedy's Class III is the most common class of partial edentulousness, 54 percent, which is more predominant in males which percent. According to a study conducted by Madhan Kumar et al., [24] the results showed the patients' with Kennedy's Class III were found to be the most prevalent among all the groups which was fifty five percent. Kennedy's Class III dental arch was the most prevalent pattern in both maxillary and mandibular arches in a study conducted by Fayad et al., [14]. Small sample size and single centered study were the limitations in this study. Another limita-

Table 1. Representing Chi square test for independence between Partial edentulism and Gender. Chi square value of the test statistic is 8.445 with corresponding $\mathrm{p}$ value of $0.038(<0.05)$. Hence there is a statistically significant difference between gender and partial edentulism among the study population.

\begin{tabular}{|c|c|c|c|}
\hline & Value & df & Asymp. Sig. (2-sided) \\
\hline Pearson Chi-Square & 8.445 & 3 & 0.038 \\
\hline Likelihood Ratio & 8.836 & 3 & 0.032 \\
\hline $\begin{array}{c}\text { Linear-by-Linear As- } \\
\text { sociation }\end{array}$ & 0.962 & 1 & 0.327 \\
\hline No. of Valid Cases & 400 & & \\
\hline
\end{tabular}

Figure 1: Bar graph representing percentage of partially edentulous participants based on Gender distribution. $X$ axis represents the gender, Y axis represents the percentage of participants. 55\% of partially edentulous participants were males (Grey). $45 \%$ of partially edentulous participants were females(White). Males seem to have higher prevalence of partial edentulism when compared to females in the study group.

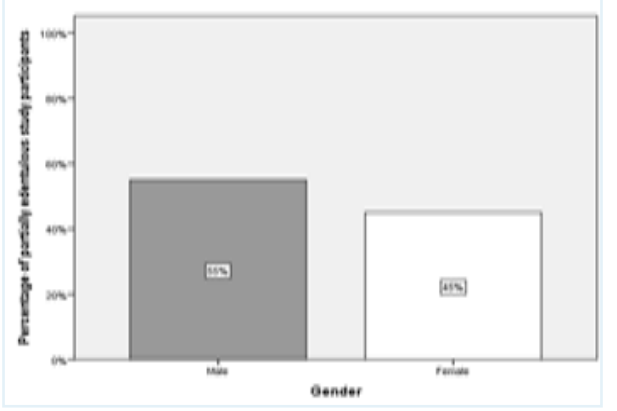


Figure 2: Bar graph representing distribution of partially edentulous study participants based on Kennedy's classification. $\mathrm{X}$ axis represents Kennedy's classification and $\mathrm{Y}$ axis represents the percentage of partially edentulous study participants. Majority of the study population represented Kennedy's class III classification (63.5\%).

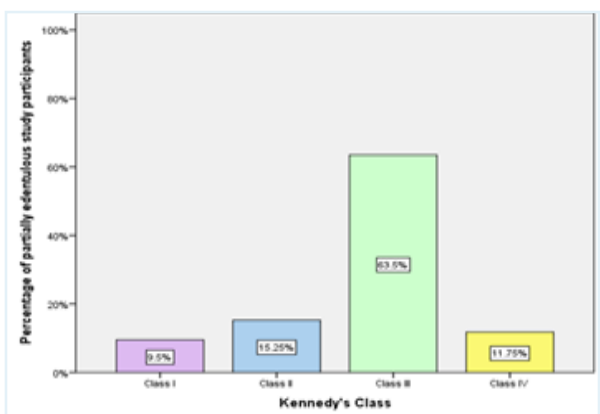

Figure 3: is a Clustered Bar graph representing the association between partial edentulism and Gender. $\mathrm{X}$ axis represents Gender and $\mathrm{Y}$ axis represents percentage of partially edentulous based on Kennedy's classification. Majority of the study population represented Kennedy's class III in male $(32.50 \%)$ and female $(31 \%)$ population. A Chi square analysis was performed to check for association between Partial edentulism and gender. Chi square value 8.445,p value of $0.038(<0.05)$. Hence there is statistically significant difference between Gender and partial edentulism among the study population.

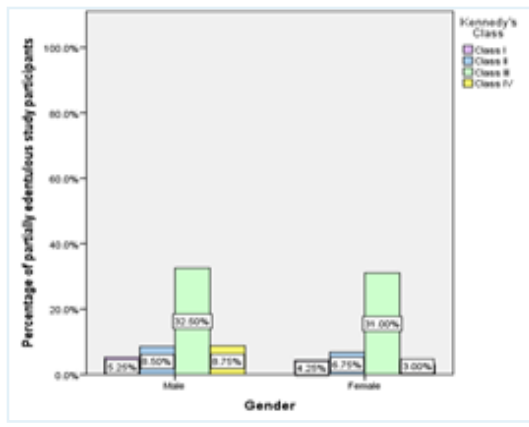

tion in this study is there is no variation in ethnicity. Future scope, the future study can be done in a larger population. Our institution is passionate about high quality evidence based research and has excelled in various fields $[28,32,47,13,31,40,46,8,26,33$, 36]. We hope this study adds to this rich legacy.

\section{Conclusion}

Within the limitations of this study, the most prevalent type of partial edentulism is Kennedy's Class III partial edentulism more common in males than females in the current study population. There is a statistically significant difference between gender and partial edentulism among the study population.

\section{References}

[1]. Abitha T, Santhanam A. Correlation between bizygomatic and maxillary central incisor width for gender identification. Braz. Dent. Sci. 2019 Oct 31;22(4):458-66.

[2]. Ajay R, Suma K, Ali SA, Kumar Sivakumar JS, Rakshagan V, Devaki V, et al. Effect of Surface Modifications on the Retention of Cement-retained Implant Crowns under Fatigue Loads: An In vitro Study. J Pharm Bioallied Sci. 2017 Nov;9(Suppl 1):S154-S160.Pubmed PMID: 29284956.

[3]. Jain AR, Nallaswamy D, Ariga P, Ganapathy DM. Determination of correlation of width of maxillary anterior teeth using extraoral and intraoral factors in Indian population: A systematic review. World J Dent. 2018 Jan;9(1):6875 .

[4]. Ashok V, Nallaswamy D, Benazir Begum S, Nesappan T. Lip Bumper Prosthesis for an Acromegaly Patient: A Clinical Report. J Indian Prosthodont Soc. 2014 Dec;14(Suppl 1):279-82.Pubmed PMID: 26199531.

[5]. Ashok V, Suvitha S. Awareness of all ceramic restoration in rural population. Research Journal of Pharmacy and Technology. 2016;9(10):1691-3.

[6]. Azeem RA, Sureshbabu NM. Clinical performance of direct versus indirect composite restorations in posterior teeth: A systematic review. J. Conserv. Dent. 2018 Jan;21(1):2-9.
[7]. Basha FY, Ganapathy D, Venugopalan S. Oral hygiene status among pregnant women. Res J Pharm Technol. 2018;11(7):3099-102.

[8]. Chandrasekar R, Chandrasekhar S, Sundari KKS, Ravi P. Development and validation of a formula for objective assessment of cervical vertebral bone age. Prog Orthod. 2020 Oct 12;21(1):38.Pubmed PMID: 33043408.

[9]. Chen F, Tang Y, Sun Y, Veeraraghavan VP, Mohan SK, Cui C. 6-shogaol, a active constiuents of ginger prevents UVB radiation mediated inflammation and oxidative stress through modulating $\mathrm{NrF} 2$ signaling in human epidermal keratinocytes (HaCaT cells). J Photochem Photobiol B. 2019 Aug; 197:111518.Pubmed PMID: 31202076.

[10]. Dhinesh B, Bharathi RN, Lalvani JI, Parthasarathy M, Annamalai K. An experimental analysis on the influence of fuel borne additives on the single cylinder diesel engine powered by Cymbopogon flexuosus biofuel. J. Energy Inst. 2017 Aug 1;90(4):634-45.

[11]. D'Souza KM, Aras M. Association between socio-demographic variables and partial edentulism in the Goan population: an epidemiological study in India. Indian J Dent Res. 2014 Jul-Aug;25(4):434-8.Pubmed PMID: 25307904.

[12]. Duraisamy R, Krishnan CS, Ramasubramanian H, Sampathkumar J, Mariappan S, Navarasampatti Sivaprakasam A. Compatibility of Nonoriginal Abutments With Implants: Evaluation of Microgap at the Implant-Abutment Interface, With Original and Nonoriginal Abutments. Implant Dent. 2019 Jun;28(3):289-295.Pubmed PMID: 31124826.

[13]. Ezhilarasan D, Apoorva VS, Ashok Vardhan N. Syzygium cumini extract induced reactive oxygen species-mediated apoptosis in human oral squamous carcinoma cells. J Oral Pathol Med. 2019 Feb;48(2):115-121.Pubmed PMID: 30451321.

[14]. Fayad MI, Baig MN, Alrawaili AM. Prevalence and pattern of partial edentulism among dental patients attending College of Dentistry, Aljouf University, Saudi Arabia. J Int Soc Prev Community Dent. 2016 Dec;6(Suppl 3):S187-S191.Pubmed PMID: 28217535.

[15]. Ganapathy D, Sathyamoorthy A, Ranganathan H, Murthykumar K. Effect of Resin Bonded Luting Agents Influencing Marginal Discrepancy in All Ceramic Complete Veneer Crowns. J Clin Diagn Res. 2016 Dec;10(12):ZC67ZC70.Pubmed PMID: 28209008.

[16]. Ganapathy DM, Kannan A, Venugopalan S. Effect of coated surfaces influencing screw loosening in implants: A systematic review and meta-analysis. World J. Dent. 2017 Nov;8(6):496-502.

[17]. Girija SA, Jayaseelan VP, Arumugam P. Prevalence of VIM- and GIMproducing Acinetobacter baumannii from patients with severe urinary tract 
infection. Acta Microbiol Immunol Hung. 2018 Dec 1;65(4):539-550.Pubmed PMID: 30111160.

[18]. Govindaraju L, Neelakantan P, Gutmann JL. Effect of root canal irrigating solutions on the compressive strength of tricalcium silicate cements. Clin Oral Investig. 2017 Mar;21(2):567-571.Pubmed PMID: 27469101.

[19]. Jain AR. Prevalence of partial edentulousness and treatment needs in rural population of South India. World J. Dent. 2017 Jun;8(3):213-7.

[20]. Ranganathan H, Ganapathy DM, Jain AR. Cervical and Incisal Marginal Discrepancy in Ceramic Laminate Veneering Materials: A SEM Analysis. Contemp Clin Dent. 2017 Apr-Jun;8(2):272-278.Pubmed PMID: 28839415.

[21]. Jeyapalan V, Krishnan CS. Partial Edentulism and its Correlation to Age, Gender, Socio-economic Status and Incidence of Various Kennedy's Classes- A Literature Review. J Clin Diagn Res. 2015 Jun;9(6):ZE14-7.Pubmed PMID: 26266237

[22]. Jyothi S, Robin PK, Ganapathy D. Periodontal health status of three different groups wearing temporary partial denture. Res J Pharm Technol . 2017;10(12):4339-42.

[23]. Kannan A, Venugopalan S. A systematic review on the effect of use of impregnated retraction cords on gingiva. Res J Pharm Technol. 2018;11(5):2121-6.

[24]. Madhankumar S, Mohamed K, Natarajan S, Kumar VA, Athiban I, Padmanabhan TV. Prevalence of partial edentulousness among the patients reporting to the Department of Prosthodontics Sri Ramachandra University Chennai, India: An epidemiological study. J Pharm Bioallied Sci. 2015 Aug;7(Suppl 2):S643-7.Pubmed PMID: 26538935.

[25]. Manohar J. A Study on the Knowledge of Causes and Prevalance of Pigmentation of Gingiva among Dental Students. Indian J Public Health Res Dev. 2019 Aug 1;10(8):95.

[26]. Mathew MG, Samuel SR, Soni AJ, Roopa KB. Evaluation of adhesion of Streptococcus mutans, plaque accumulation on zirconia and stainless steel crowns, and surrounding gingival inflammation in primary molars: randomized controlled trial. Clin Oral Investig. 2020 Sep;24(9):1-6.Pubmed PMID: 31955271

[27]. Muthukrishnan A, Warnakulasuriya S. Oral health consequences of smokeless tobacco use. Indian J Med Res. 2018 Jul;148(1):35-40.

[28]. Pc J, Marimuthu T, Devadoss P, Kumar SM. Prevalence and measurement of anterior loop of the mandibular canal using CBCT: A cross sectional study. Clin Implant Dent Relat Res. 2018 Apr 6;20(4):531-4.

[29]. Vijayashree Priyadharsini J, Smiline Girija AS, Paramasivam A. In silico analysis of virulence genes in an emerging dental pathogen A. baumannii and related species. Arch Oral Biol. 2018 Oct;94:93-98.Pubmed PMID: 30015217

[30]. Priyanka S, Kaarthikeyan G, Nadathur JD, Mohanraj A, Kavarthapu A. Detection of cytomegalovirus, Epstein-Barr virus, and Torque Teno virus in subgingival and atheromatous plaques of cardiac patients with chronic periodontitis. J Indian Soc Periodontol. 2017 Nov-Dec;21(6):456-460.Pubmed PMID: 29551863.

[31]. Ramadurai N, Gurunathan D, Samuel AV, Subramanian E, Rodrigues SJ. Effectiveness of $2 \%$ Articaine as an anesthetic agent in children: randomized controlled trial. Clin. Oral Investig. 2019 Sep;23(9):3543-50.

[32]. Ramesh A, Varghese S, Jayakumar ND, Malaiappan S. Comparative estimation of sulfiredoxin levels between chronic periodontitis and healthy patients - A case-control study. J Periodontol. 2018 Oct;89(10):1241-1248.Pubmed PMID: 30044495.

[33]. R H, Ramani P, Ramanathan A, R JM, S G, Ramasubramanian A, et al.
CYP2 C9 polymorphism among patients with oral squamous cell carcinoma and its role in altering the metabolism of benzo[a]pyrene. Oral Surg Oral Med Oral Pathol Oral Radiol. 2020 Sep;130(3):306-312.Pubmed PMID: 32773350.

[34]. Sadig WM, Idowu AT. Removable partial denture design: a study of a selected population in Saudi Arabia. J Contemp Dent Pract. 2002 Nov 15;3(4):40-53.Pubmed PMID: 12444401.

[35]. Abdel-Rahman HK, Tahir CD, Saleh MM. Incidence of partial edentulism and its relation with age and gender. Zanco J Med Sci. 2013;17(2):463-70.

[36]. Samuel SR. Can 5-year-olds sensibly self-report the impact of developmental enamel defects on their quality of life? Int J Paediatr Dent. 2021 Mar;31(2):285-286.Pubmed PMID: 32416620.

[37]. Selvan SR, Ganapathy D. Efficacy of fifth generation cephalosporins against methicillin-resistant Staphylococcus aureus-A review. Res J Pharm Technol. 2016;9(10):1815-8.

[38]. Shamdol Z, Ismail NM, Hamzah NT, Ismail AR. Prevalence and associated factors of edentulism among elderly Muslims in Kota Bharu, Kelantan, Malaysia. J. Islam. Med. Assoc. N. Am. 2008 Nov 1;40(4).

[39]. Sheriff K, Santhanam A. Knowledge and Awareness towards Oral Biopsy among Students of Saveetha Dental College. Res J Pharm Technol. 2018;11(2):543-6.

[40]. Sitharthan R, Sundarabalan CK, Devabalaji KR, Yuvaraj T, Mohamed Imran A. Automated power management strategy for wind power generation system using pitch angle controller. Meas. Control. 2019 Mar;52(3-4):169-82.

[41]. Sridharan G, Ramani P, Patankar S, Vijayaraghavan R. Evaluation of salivary metabolomics in oral leukoplakia and oral squamous cell carcinoma. J. Oral Pathol. Med. 2019 Apr;48(4):299-306.

[42]. Subasree S, Murthykumar K. Effect of aloe vera in oral health-A review. Res J Pharm Technol. 2016;9(5):609-12.

[43]. Venugopalan S, Ariga P, Aggarwal P, Viswanath A. Case Report: Magnetically retained silicone facial prosthesis. Niger. J. Clin. Pract. 2014 Mar 27;17(2):260-4

[44]. Venu H, Raju VD, Subramani L. Combined effect of influence of nano additives, combustion chamber geometry and injection timing in a DI diesel engine fuelled with ternary (diesel-biodiesel-ethanol) blends. Energy. 2019 May 1;174:386-406.

[45]. Vijayalakshmi B, Ganapathy D. Medical management of cellulitis. Res J Pharm Technol. 2016;9(11):2067-70.

[46]. Vijayashree Priyadharsini J. In silico validation of the non-antibiotic drugs acetaminophen and ibuprofen as antibacterial agents against red complex pathogens. J Periodontol. 2019 Dec;90(12):1441-1448.Pubmed PMID: 31257588.

[47]. Vijayashree Priyadharsini J, Smiline Girija AS, Paramasivam A. In silico analysis of virulence genes in an emerging dental pathogen A. baumannii and related species. Arch Oral Biol. 2018 Oct;94:93-98.Pubmed PMID: 30015217.

[48]. Wang Y, Zhang Y, Guo Y, Lu J, Veeraraghavan VP, Mohan SK, et al. Synthesis of Zinc oxide nanoparticles from Marsdenia tenacissima inhibits the cell proliferation and induces apoptosis in laryngeal cancer cells (Hep-2). J Photochem Photobiol B. 2019 Dec;201:111624.Pubmed PMID: 31722283.

[49]. Wu F, Zhu J, Li G, Wang J, Veeraraghavan VP, Krishna Mohan S, et al. Biologically synthesized green gold nanoparticles from Siberian ginseng induce growth-inhibitory effect on melanoma cells (B16). Artif Cells Nanomed Biotechnol. 2019 Dec;47(1):3297-3305.Pubmed PMID: 31379212. 